\title{
De tyske undervandsbåde på bunden af Hørup Hav
}

2. Verdenskrigs vraggods

\author{
af ANTON MARCKMANN
}

Om morgenen den 5. maj 1945 skete der en række bemærkelsesværdige sænkninger af ubåde i farvandet ud for Høruphav på Als. Da kapitulationen var en kendsgerning, besluttede de tyske ubådschefer at selvsænke deres både. Ubådene i Hørup Hav udgjorde det største antal selvsænkede ubåde $\mathrm{i}$ danske farvande. I artiklen belyses bådenes historie fra krigsafslutningen til i dag. Forfatteren har samlet oplysninger om otte ubåde og sandsynliggør, at en enkelt af disse ikke er blevet tømt af vragfiskere.

Hørup Hav er den ca. $20 \mathrm{~km}$ lange, fjordlignende udløber fra Sønderborg bugt, der strækker sig ind mellem Sydals og Kegnæs for mod øst at ende ved Drejet, som er en af strømforholdene naturskabt tange mellem de to områder. Oprindelig var de adskilte af en rivende smelteflod, da isen trak sig tilbage efter sidste istid, hvilket forklarer de betragtelige vanddybder, som i dag har deres maksimum på 35 meter i den vestlige del. ${ }^{1}$ Også på tværs er bugten anselig med en største bredde på godt $2 \mathrm{~km}$ mod vest og 1,5-2 km i den østligste del - den, der i folkemunde benævnes Lillehavet. Nærkontakten til havet har præget og præger stadig naturen og livet, både på Als - og på Kegnæssiden. Selve bysamfundet Høruphav er vokset op omkring et gammelt fiskerleje.

1. Verdenskrig og årene forinden satte sit mærkbare aftryk på Høruphav i form af torpedoindskydningsstationen på Hørup Klint (Klinten) og de aktiviteter, der udgik fra den. ${ }^{2}$

Også under 2. Verdenskrig blev området efter den tyske besættelse af Danmark inddraget i militært øjemed. Hørup Klint blev udbygget til en tysk forsøgsstation, hvor der bl.a. eksperimenteredes med radarpejlingssystemer, og farvandet blev øvelsesplads for tyske undervandsbåde. ${ }^{3}$

Da krigens udfald var uafvendeligt, befalede den tyske marineoverkommando den 30. april 1945, at alle tyske krigsskibe skulle sæn- 


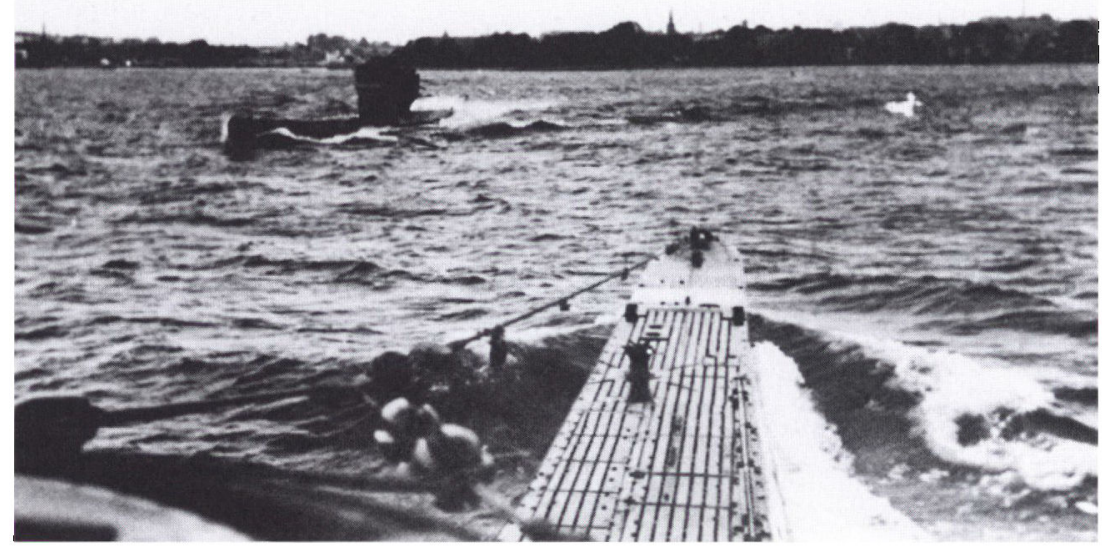

To tyske ubåde (type VII) passerer hinanden tæt ved indsejlingen til Horup Hav. Foto: Tysk marinesoldat 1943, Lokalhistorisk arkiv i Hørup.

kes ved modtagelsen af kodeordet Regenbogen. Den betingelsesløse kapitulation trådte i kraft den 5. maj kl. 8, hvorpå de tyske ubådschefer $\mathrm{i}$ de tyske og danske farvande og havne besluttede at selvsænke deres både, skønt kodeordet ikke var udsendt. De begrundede deres aktioner med, at kapitulationen og betingelserne var skrevet under tvang og uden underskrift af den øverste flådechef Karl Dönitz, der efter Hitlers selvmord den 30 . april var udnævnt til midlertidig rigspræsident. I alt 216 ubåde sænkedes ved egen hånd i dagene 4 . og 5. maj, heraf ifølge opgørelserne hele $67 \mathrm{i}$ Gelting bugt/Flensborg fjord og seks i Hørup Hav. ${ }^{4}$ De sidstnævnte udgjorde det største kontingent selvsænkede tyske ubåde i danske farvande. Herudover gik enkelte ned i Århusbugten og omkring Okseøerne i Flensborg Fjord.

Under morgenroture med seniorroerne i Høruphav roklub har vi ofte talt om de ubåde, hvis vrag vi ror henover, men som vi i virkeligheden ikke ved ret meget om. I hvert fald er der nedfældet meget lidt om de begivenheder, der dengang fandt sted $\mathrm{i}$ dette farvand. Dette gav inspirationen til denne artikel, som vil søge at belyse historien bag de sænkede ubåde fra tiden omkring krigsafslutningen til i dag. 


\section{Krigsaktiviteter i Hørup Hav i sidste del krigen}

En række personer, som nævnes i det følgende, boede under besættelsen som drenge eller unge mænd tæt på Hørup Hav og sejlede ofte på havet i deres joller eller fiskede her sammen med deres fædre. De fortæller samstemmigt om en stigende aktivitet af tyske ubåde $i$ farvandet, efterhånden som krigen skred frem. Såvel i Lillehavet som i den vestlige del udførtes der ned- og uddykningsmanøvrer og sejlads i neddykket tilstand som led $\mathrm{i}$ afprøvning af fartøjernes funktioner og oplæring af mandskaberne. Det var tydeligt, at der også fandt øvelser sted mellem ubådene og forsøgsstationen på Klinten. Nogle ubåde havde station i Sønderborg, andre lå i længere tid opankrede midt i strømmen. Besætningen bestod af ganske unge matroser, der undertiden roede $\mathrm{i}$ land på Kegnæs og tiltuskede sig friske madvarer. I farvandet befandt sig også to mindre vagtskibe eller minestrygere, der havde til opgave at spærre og kontrollere indsejlingen til Hørup Hav. ${ }^{5}$

Som krigsfronten i årene 1944 og 1945 nærmede sig, sporedes også krigens dramatik og alvor i det lille, fredelige samfund omkring Hørup Hav. Beboerne havde de allieredes bombetogter over Nordtyskland så at sige i forste parket med hyppige overflyvninger, og om natten var de vidner til lyskasternes søgen efter de allieredes fly og til bragene og brandskæret efter bombardementerne, som blandt andet var rettet mod de tyske ubådsværfter på Germaniawerft i Kiel. Også ubådene i Hørup Hav tiltrak sig engelske og amerikanske jagerpiloters opmærksomhed. Der indtraf flere episoder, hvor jagere dykkede ned og beskød dem. I juni 1944 beskød en tysk ubåd i Lillehavet to lavtflyvende engelske fly uden dog at ramme, ${ }^{6}$ og i september samme år overværede den 17-årige Hans Mathiesen, Høruphav, en engelsk jagers angreb på en tysk ubåd i Lillehavet. Han var i færd med at plukke brombær fra et krat mellem det gamle Høruphav og det minerede område omkring forsøgsstationen på Hørup Klint, da jageren med tydelige R.A.F. kendemærker pludselig dukkede op fra vest og strøg henover havoverfladen i få meters højde, medens den affyrede en maskinkanonsalve mod en ret stor tysk ubåd, der opererede $i$ farvandet midtvejs ude. Mandskabet blev fuldstændig overrumplet, nogle sprang i vandet, men intet yderligere skete. Kort efter satte ubåden kursen mod Sønderborg med flaget på halv - angrebet havde kostet menneskeliv. 


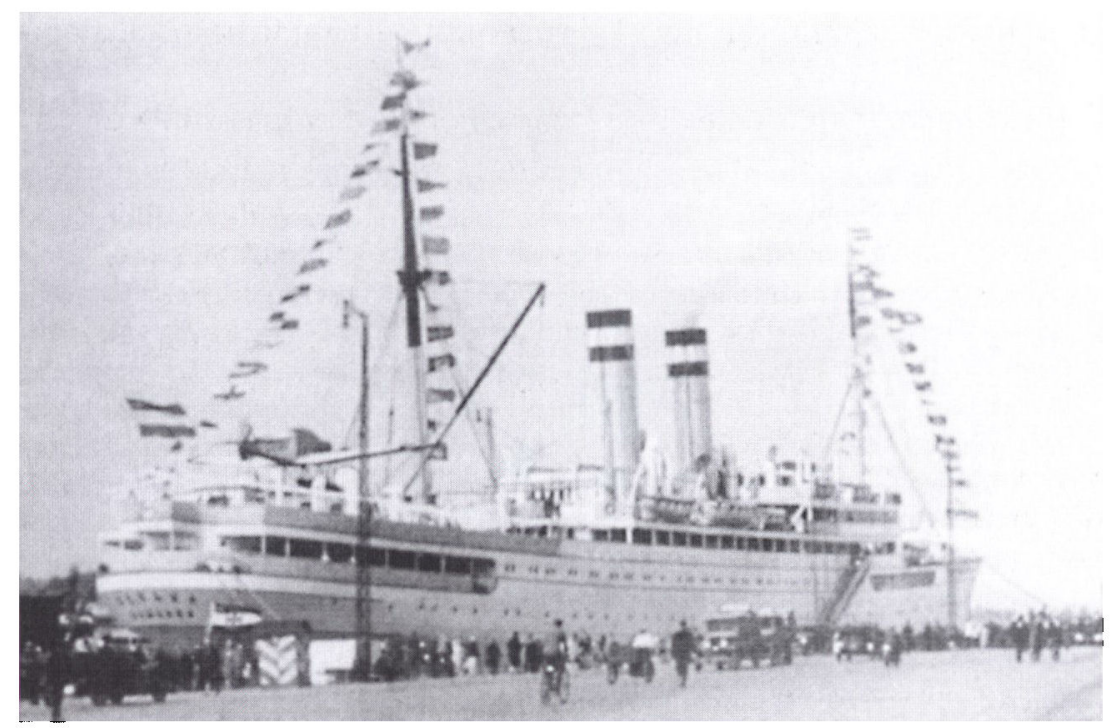

Skibet "Oceana« med en kapacitet på 720 passagerer lå $i$ Horup Hav med et stort antal fordrewne tyske civile ombord, indtil disse kunne anbringes i flygtningelejren på Klinten. Skibet blev efter krigen forst engelsk, senere russisk krigsbytte. Gengivet efter H. Schön: Hitlers Traumschiffe. Verlag Arndt, Kiel 2000.

Også på andre måder mærkedes krigens dønninger i Hørup Hav, således ankrede kort før krigsafslutningen to store værkstedspramme fra Stettin med flygtninge op ud for Mintebjerghav, ${ }^{7}$ og et større passagerskib »Oceana«, et tidligere »Kraft durch Freude«-turistskib, lå i længere tid i farvandet med et stort antal fordrevne tyske civile ombord, indtil disse kunne anbringes i flygtningelejren på Klinten.

\section{Hvad skete i Hørup Hav den 5. maj 1945 om morgenen?}

Øjenvidneberetninger fra Sydalssiden

Følgende er baseret på et interview med Peter Christensen (Pæ Maler) i Mintebjerg på Sydals fra oktober 2005. Den 86-årige åndsfriske hjemmefødning og tidligere maler er i besiddelse af en glimrende hukommelse og et stort lokalkendskab, der, parret med hans interesse og indsigt $\mathrm{i}$ egnens geografi og historie samt de optegnelser, han i tidens løb har gjort, gør ham til en væsentlig og pålidelig kilde for den, der 
vil søge oplysninger om, hvad der er sket og hændt her i lokalområdet.

Han boede under sidste del af krigen med sin familie $i$ aftægten ved sine svigerforældres gård i Mintebjerg. Fra gårdens højtliggende marker, der skråner fra 33 meters højde ned til havet, er der en storslået udsigt over Lillehavet til Kegnæs og endnu videre, hvilket bidrager til at gøre hans iagttagelser om hændelserne $\mathrm{i}$ farvandet yderst præcise.

Lørdag den 5. maj 1945, da budskabet om krigens afslutning og de tyske troppers kapitulation var blevet bekendt, overværede han ved 8-tiden selvsænkningen af to tyske ubåde i Lillehavet. Udsynet fra det mod havstokken skrånende terræn var ideelt med en afstand til begivenhederne på 1-1,5 km. Den ene ubåd blev sænket mellem Mintebjerghav/Ørhage og Hjortholm (max. dybde 17-18 m) hen mod Kegnæs rev. Denne båd er senere fundet af bjergningsmandskab, og Pæ Maler mener at have haft kontakt med båden under ålestangning i 1957. Den anden blev sænket lidt østligere mellem Mintebjerghav/ Vibæk og Kongshoved på Kegnæs (max. dybde 14-15 m), nærmere Kegnæs end Als. Denne båd synes lokaliseret adskillige år senere.

Der var tale om ret små ubåde, formentlig af typen XXIII med en besætning på 14 mand. Sænkningsmandskabet åbnede for bundventilerne, hvorefter ubådene sank $\mathrm{i}$ løbet af et par minutter under samtidig afgang af en vand/luftstråle op gennem kommandotårnet. De forsvandt fra havoverfladen uden forudgående hørlige eller synlige eksplosioner, efter at sænkningsmandskabet forinden var blevet afhentet af en mindre båd.

Ejnar Valentin (E.V.), Høruphav, der som dreng boede på Toften i det gamle Høruphav, og som ofte fiskede fra robåd sammen med sin far, oplyser, at der i krigens sidste dage befandt sig hele 11 tyske ubåde i farvandet. Heraf lå fire mindre opankrede klods på kysten ved den østlige del af det gamle Høruphav, to og to på hver sin side af et fragtskib "Malaga " med hjemsted i le Havre. Skibet, der et par måneder tidligere havde transporteret tyske civilflygtninge til Sønderborg, var herefter sat på grund i Høruphav, da det var beskadiget, muligvis som følge af, at det i oktober 1943 under konvojsejlads med jernmalm fra Nordnorge til Tyskland var blevet beskudt og bombet af en amerikansk fly-eskadrille i farvandet ud for Bodø. ${ }^{8}$

Af de omtalte fire ubåde gik de to ned med åbne bundventiler om morgenen og op ad formiddagen den 5 . maj 1945, begge sejlende med motoren slået til og uden mandskab ombord. Den ene over mod Keg- 


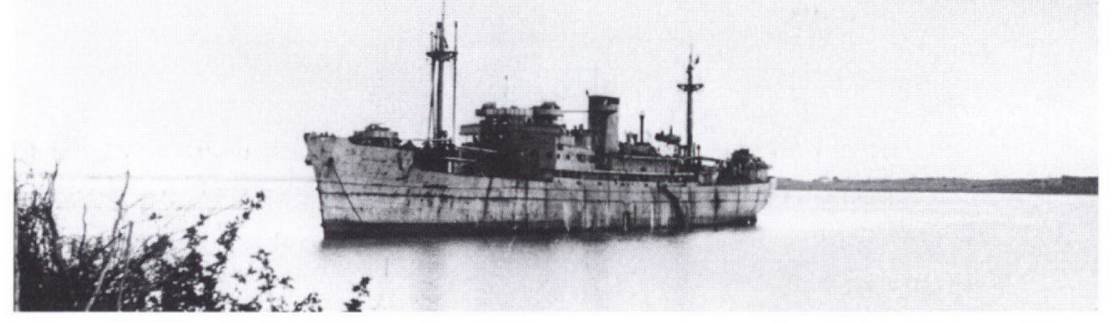

Det beskadigede fragtskib "Malaga«, som transporterede tyske civilflygtninge til Sønderborg. Skibet blev sat på grund ud for Kleften. Horuphav, da det havde pådraget sig en skade, muligvis som folge af beskydning og bombning af en amerikansk eskadrille. Efter at være slæbt fri af Oceana afsejlede det natten mellem den 5. og 6. maj $i$ retning Flensborg. Privat foto fra den 5. maj 1945, efter at ubådene var sænkede.

næs Færge, den anden tæt ved kosten ud for Kegnæs Rev. De to andre, som utvivlsomt er de samme, som Pæ Maler iagttog, blev sejlet om i Lillehavet og sænket her. Desuden har E.V. kendskab til endnu en sænket (og senere hævet) ubåd i Lillehavet. Yderligere kunne der på afstand gennem lysningen mellem Trilleskoven og gruppen af de karakteristiske fyrretræer iagttages, at der gik en ubåd ned længere mod vest i retning mod Stenholt. Mandskaberne på de mange ubåde var i god tid før sænkningerne blevet indkvarteret i den store sal på Hotel Baltic, hvor de den 4. maj om aftenen kunne overvære lokalbefolkningen fejre befrielsen $i$ andre lokaler.

Et andet øjenvidne, dengang en stor skoledreng på 14 år, Henry Jessen, Høruphav, så samme formiddag fra Kløften på et lille højdedrag nær kysten i det gamle Høruphav også de to mindre ubåde gå ned over mod Kegnæs. Derimod havde han ikke observeret sænkningerne i Lillehavet. Næste dag drev nysgerrigheden ham i en lille sejljolle ud til sænkningsstedet, men han vendte hurtigt om, da han blev beskudt fra land, formentlig af frihedskæmpere eller englænderne.

Arne Jensen, Havbo, Høruphav, var 7 år gammel, da sænkningerne fandt sted. Han fiskede meget med sin far og kan berette, at der i lang tid efter den 5. maj 1945 observeredes en stor olieplet i Lillehavet i området mellem Vibæk og Kongshoved, utvivlsomt stammende fra den her sænkede ubåd. A. J. er selv erhvervsfisker og kender farvandet til bunds.

Til de yderligere ubådssænkninger i den vestlige del af Hørup Hav, 
som vil blive omtalt i det følgende, har de her refererede meddelere ikke været øjenvidner.

\section{Øjenvidneberetning fra Kegnæs}

I den vestlige del af Hørup Hav ("æ gaf «), dvs. strækningen fra Kegnæs Færge/Trillen til en linje mellem Kegnæs ende og østligste del af Sønderskoven, fandt der også samtidigt en række ubådssænkninger sted, hvilket fremgår af følgende beretning af Viggo Høy, Grønmark 9, Kegnæs i interview i oktober 2005. Viggo Høy (V.H.) bor i sit barndomshjem på Kegnæs tæt på den vestlige del af Hørup Hav med en smuk udsigt over til Sønderskoven og Stenholt, og går man lidt op på marken, ligger Lambjerglund, Trillen og Høruphav i synsfeltet.

Som dreng legede han næsten daglig efter skolegang sammen med kammerater omkring den store sten, der ligger i strandkanten ved Grønmark. Ofte sejlede de ud i en jolle og fiskede. Han har et indgående og livslangt kendskab til farvandet og området.

Omkring den 1. maj 1945, da V.H. var knap 9 år gammel, var to større ubåde opankrede ud for den store sten, og i de følgende dage sluttede yderligere to sig til. De fire ubåde lå nu på rad og række midt $\mathrm{i}$ farvandet med stævnen mod V/SV og med ca. 100 meters mellemrum.

Lørdag den 5. maj, mens familien sad ved morgenbordet og inden V.H. skulle cykle i skole, hørtes kort før kl. 8 et brag, og der mærkedes en rystelse $\mathrm{i}$ huset. Familien løb straks ud på gårdspladsen. Her blev de vidne til, at den forreste ubåd (længst mod vest) var i færd med at synke, brækket midt over som følge af en eksplosion midtskibs. Herefter gik de tre andre ned én efter én, efter at bundventilerne var blevet åbnet af sænkningsmandskabet, der hastigt roede fra båd til båd.

Den ubåd, som E.V. fra Toften i Høruphav så gå ned i den vestlige del af Hørup Hav, er utvivlsomt én af disse fire. At hr. Høy senior straks tog pejling af sænkningsstederne ved hjælp af faste punkter tæt på gården og på Als, skulle vise sig at blive til stor hjælp ved senere eftersøgning og lokalisation af vragene. Det siger sig selv, at V.H. ikke kom i skole den dag, og i øvrigt var skolegangen vel suspenderet "på grund af glæde«. I tiden herefter kunne man i stille vejr se brede oliepletter på havoverfladen, når dieselolien lækkede ud fra tankene $\mathrm{i}$ de sænkede ubåde, og olien kunne tydeligt lugtes under bestemte vindforhold. 


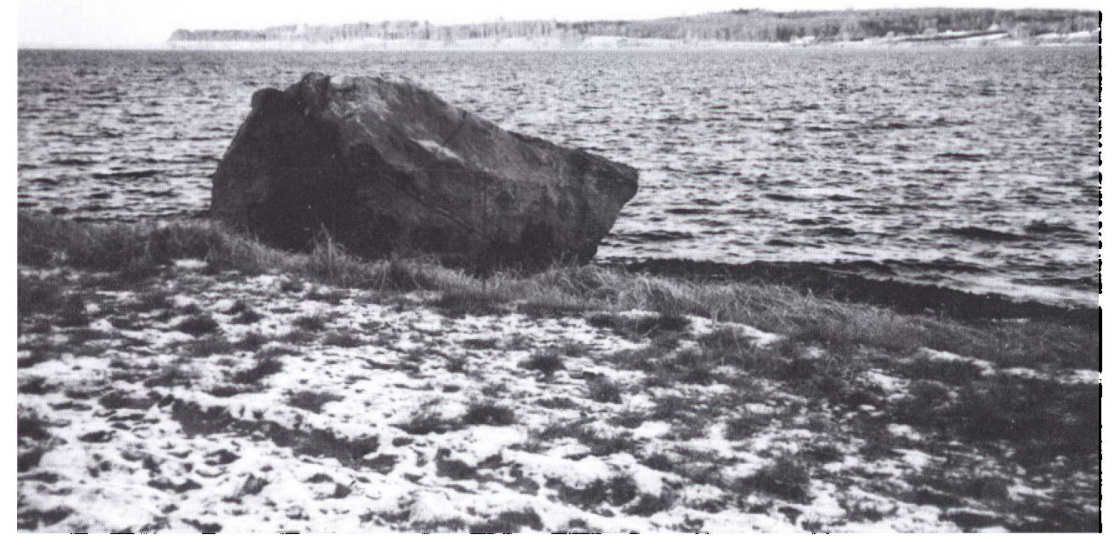

Den store sten ud for Gronmark på Kegnæs med Sønderskoven på den anden side af "x gafu. Ud for den store sten lå fire ubåde opankrede lordag den 5. maj 1945. Kort far $k l .8$ lød et brag, hvorefter ubäden langst mod vest sank, brækket midt over som folge af en eksplosion midtskibs. Herefter gik de tre andre ned én efter én, efter at bundventilerne var åbnet af sænkningsmandskabet, der hastigt roede fra båd til båd. Foto: Anton Marckminn.

V.H. har siden dyrket sin interesse for de sænkede ubåde (og ubåde i det hele taget), også om de senere bestræbelser på at lokalisere og bjerge dem. Ubådene var jo allieret krigsbytte og derfor urørlige, men nogen tid efter befrielsen blev V.H.'s far, Peter Høy, opsøgt af nogle befalingsmænd fra et dansk marinefartøj, der i flere dage havde sejlet søgende rundt $i$ farvandet. De havde fået oplysning om, at han kendte til de sænkede ubådes placering, og efter hans anvisninger lykkedes det i løbet af kort tid ved hjælp af paravaner (flydere) at få hold i de eftersøgte ubåde. At det $i$ alt væsentligt forholder sig, som V.H. her oplyser, vil senere blive bekræftet af kilder, som fastlægger tidspunktet for disse hændelser til oktober 1946.

Efter de her beskrevne øjenvidners udsagn synes der således at være sænket et sted mellem seks og ni ubåde i Hørup Hav den 5. maj 1945. 
Horup skous $=54.55 \mathrm{~N}$

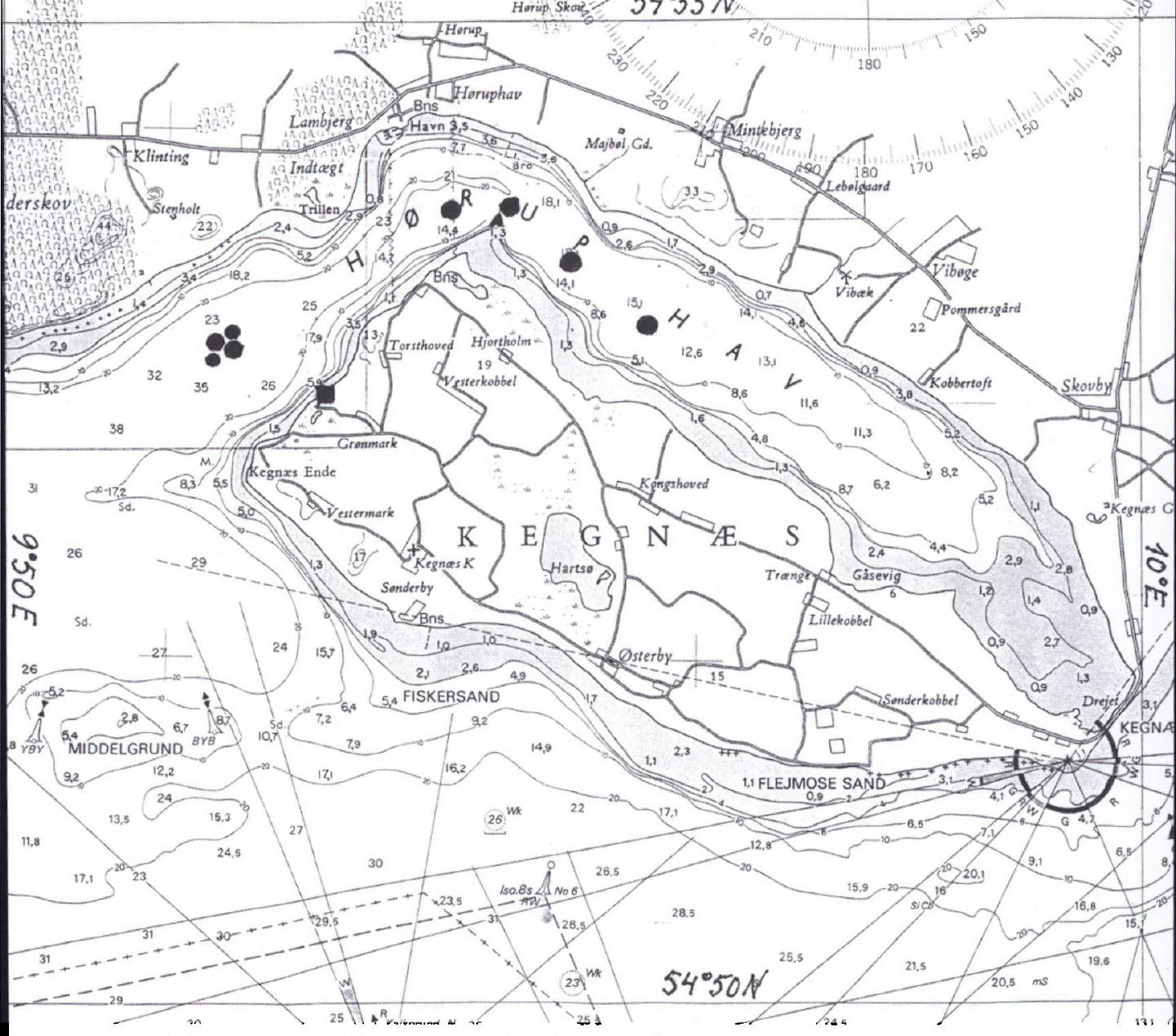

Kort over Hørup Hav og omgivelser. Med mork cirkel er markeret de omtrentlige positioner for sænkede ubaide, baseret $p a ̊$ oplyste koordinater fra dykkerrapporter og på ajenvidneskildringer. Den store sten ved Granmark er aftegnet som en mark firkant. Gengivet efter kort over Flensborg Fjord og Lillebælt. Farvandsdirektoratet 1986.

\section{Hvad siger tyske og engelske kilder om de sænkede} ubåde?

Tyske opgørelser over sænkede ubåde angiver, at der den 5. maj 1945 blev selvsænket fem eller seks ubåde i Hørup Hav, en engelsk kilde angiver antallet til seks. ${ }^{9}$ Disse opgørelser baserer sig på tyske myndigheders officielle arkiverede rapporter om samtlige ubådes skæbner, arkiver, som efter krigsafslutningen blev beslaglagt af de allieredes kontrolkommission, og som er tilgængelige og offentliggjorte. ${ }^{10}$ Senere opdateringer har bragt en del korrektioner for dagen. Der er 
Tysk ubåd, type VII C. Lxngde: 67 m, besxtning: 44 mand, totalvagt: 1070 tons. Type IX C var storre: længde $77 \mathrm{~m}$, besxtning 48-56 mand, totalvagt 1540 tons. To (måske tre) ubåde af disse typer sænkedes den 5. maj 1945 i Horup Hav ud for Gronmark på Kegnas. Gengivet efter E. Rössler: Die deutschen U-Boote und ihre Werften. Bernard \& Graefe, Koblenz 1990.

således ikke fuld overensstemmelse mellem de forskellige kilders angivelser af bådenes sænkningssteder, og med hensyn til hvilke ubådstyper, det drejede sig om, er oplysningerne ligeledes noget divergerende. Men det skulle dreje sig om typerne XXI, VII C og IX C, alle store oceangående ubåde, desuden om typen XXIII, som er en mindre ubåd, der opererede i kystnære farvande. ${ }^{11}$ Om typen XXI skal nævnes, at den var den mest moderne udgave af de tyske ubåde, som blev bygget $\mathrm{i}$ betydeligt antal under sidste del af krigen, og hvorom det hævdes, at den måske kunne have ændret udfaldet af slaget om Atlanten, hvis den var kommet i aktion. Det kom den imidlertid ikke. Efter en gennemgang af en opgørelse over samtlige tyske ubådes skæbne kan det dog ses, at der ikke blev sænket sådanne af type XXI i Hørup Hav. Derimod ligger der adskillige på bunden af Gelting bugt. Type VII, der udgjorde størsteparten af de opererende ubåde, var frygtet bl.a. for deres ulve-kobbel overfald på de allieredes konvojer i Atlanten. Type IX C ubåden var noget større end type VII C. ${ }^{12}$ Det er dog yderst tvivlsomt, om nogen af de i Hørup Hav selvsænkede undervandsbåde nogensinde nåede at komme i aktion mod de allierede. De fleste figurerer som træningsfartøjer. For type XXIII-bådenes vedkommende havde de kun været $i$ brug 1-3 måneder efter afgivelsen fra værfterne. ${ }^{13}$

De enkelte ubåde var ikke navngivne, men havde et nummer. Der ses således fra ovennævnte opgørelser, at der den 5. maj 1945 i Hørup Hav på positionen $54^{\circ} 53 \mathrm{~N} / 9^{\circ} 50 \mathrm{E}$ blev sænket en VII C ubåd med nummeret U-351 samt en type XXIII med nummeret 4704. Yderligere sænkedes i farvandet en IX C'er med nummer U-1234 og fire type XXIII ubåde med numrene U-4701, 4702, 4703 og 2352. På sænkningstidspunktet førtes ubådene af unge »Oberleutnanten«, som i oversig- 
$=2$

Tysk ubåd type XXIII. Lxngde: 34,7 m, besætning: 14 mand, totalvægt: 275 tons. En del ubåde af denne type gik ned $i$ Horup Hav den 5. maj 1945. De fleste $i$ den astlige del (Lillehavet). Gengivet efter $E$. Rössler: Die deutschen U-Boote und ihre Werften. Bernard E Graefe, Koblenz 1990.

terne står opførte med navns nævnelse. For nogle af bådene er sænkningspositionen anført, men et blik på søkortet afslører imidlertid, at de opgivne koordinater for fx U-4701 må tages med forbehold, og at de ikke kan være korrekte, hvis denne ubåd, som anført, skal være sænket i Hørup Hav. Angivelsen af de sænkede ubådstyper taler imidlertid ikke imod de oplysninger, som de tidligere omtalte lokale meddelere har givet.

På basis af de her refererede tyske og engelske kilder er der dokumentation for, at der er selvsænket i hvert fald seks, måske syv ubåde i Hørup Hav den 5. maj 1945.

\section{Hvad kan danske arkiver og kilder oplyse?}

Søværnets undersøgelser

Søværnet og Fyrdirektoratet (nu underlagt Farvandsvæsenet) havde indlysende interesse i at få fastlagt lokalisationen af de sænkede ubåde, dels af hensyn til besejlingsforholdene, men også for at få indblik i tekniske detaljer $\mathrm{i}$ bådenes konstruktion, undersøge installationer som snorkelanlæg og andet udstyr, indsamle kort, tegninger og kodemateriale og for eventuelt at hæve ubeskadigede vrag.

Med Forsvarskommandoens og Rigsarkivarens tilladelse til at benytte ikke umiddelbart tilgængeligt arkivmateriale kan følgende uddrages fra sagsmappen om de selvsænkede tyske ubåde i Hørup Hav: ${ }^{14}$ Da Marineministeriet var $i$ besiddelse af oplysninger om, at der i Hørup Hav skulle findes 9-11 sænkede ubåde, heraf 5-6 i den vestlige del og 4-5 i den østlige del, blev der beordret en eftersøgning for at klarlægge deres placering og for evt. at typebestemme dem.

Resultatet af denne eftersøgning, der fandt sted i dagene 22.-24. 
oktober 1946, foreligger i en rapport til ministeriet, dateret den 30 . oktober 1946.

Undersøgelsesholdet bestod af en kaptajnløjtnant, en maskinmester samt en kvartermester - denne varetog dykkeropgaverne, og holdet arbejdede sammen med marinestationen i Sønderborg, der bl.a. stillede kuttere og en dykker til rådighed. Eftersøgningen foregik både med dræg og med søgewire, udspændt mellem to kuttere, men var hæmmet af, at den blev foretaget uden udstyr til ekkolodning. En professionel dykker fra Sønderborg bidrog med oplysninger om vragenes placering ud fra den viden, han var i besiddelse af, efter at han i 1945 havde assisteret engelske styrker ved sprængninger af de sænkede ubåde $i$ farvandet.

Eftersøgningen startede i den østlige del af Hørup Hav, men trods indhentede oplysninger om placering af vrag lykkedes det ikke at lokalisere sådanne, hvorefter man koncentrerede sig om den vestlige del ud for Grønmark, hvor dykkeren fik kontakt til to ubåde.

Den ene, med en anslået vægt på 700-740 tons, lå i 25 meters dybde, sunket dybt ned i mudderet, så kun dækket ragede op. Den havde en sprængning i styrbords side bag broen. Den anden lå i 22 meters dybde med en anslået vægt på ca. 1200 tons og var tilsyneladende ubeskadiget. (Det kan dreje sig om en type VIIC og en type IXC ubåd). Deres positioner blev bestemt ved fikspunkter på land, som projiceret på søkortet nøje svarer til de koordinater, som andre dykkerhold senere fastlagde.

Rapporten omtaler, at lederen af eftersøgningen, kaptajnløjtnant E.W., den 24. oktober gik i land på Kegnæs og opsegte den tidligere omtalte Peter Høy, som gav følgende oplysninger: Om morgenen den 5. maj 1945 havde fire tyske ubåde selvsænket sig i farvandet ud for hans marker. Han havde taget mærke på dem alle, og det viste sig, at hans to vestligste mærker gik ganske tæt på de bøjer, der var udlagt, hvor de to ubåde blev fundet. Han kunne endvidere meddele, at den vestligste og den østligste af bådene var af mindre typer, medens de to midterste var store både. De to store gik ned uden at være sprængt, medens de to mindre blev beskadiget ved eksplosion i forbindelse med sænkningen.

Eftersøgningen fortsatte efter de to andre både, der skulle ligge $\mathrm{i}$ nærheden af de fundne, men blev indstillet efter $2 \frac{1}{2}$ døgns forgæves forsøg, da bundforholdene gjorde området uoverskueligt.

Søværnets eftersøgning havde således kun kunnet finde to af de sænkede ubåde. 


\section{"Efterretninger for Søfarende"}

Farvandsvæsenets publikation er gennemset for årene 1945-1952. I publikation nr. 22/1947 og nr. 1/1948 er under kategorien »Fortegnelse over Vrag « oplyst, at der på positionen $54^{\circ} 53,2 \mathrm{~N} / 9^{\circ} 52,6 \mathrm{E}$ skulle ligge 5-6 ubådsvrag på havbunden og 4-5 vrag på positionen $54^{\circ} 54,1 \mathrm{~N} / 9^{\circ} 54,9 \mathrm{E}$. Begge sænkningsområder var markeret med en bøje, men vragenes dybdeplacering var ikke anført. Da disse vrag ikke figurerer i senere fortegnelser, må man gå ud fra, at de ikke længere var til hinder for sejladsen. De anførte koordinater svarer til punkter i farvandet ud for Grønmark og i farvandet mellem Høruphav og Kegnæes.

Farvandsvæesenets angivelser af, at der skulle ligge helt op til 11 ubåde på bunden af Hørup Hav, virker umiddelbart overraskende og er ikke specifikt dokumenterede. De ses dog at være identiske med de oplysninger, som Marineministeriet var i besiddelse af. Hvad sænkningspositionerne angår, er de i overensstemmelse med andres opgivelser.

\section{Hvad skete senere?}

I efterkrigsårene var der mangel på metaller, og særlig ædle metaller og bly opnåede gode priser, især i Sverige. Da der på et vist tidspunkt blev givet tilladelse til bjergning fra de sænkede ubåde, stod bjergningsselskaberne på spring og klar til - efter indhentet tilladelse hos myndighederne - at ophente og afsætte deres værdifulde indhold, først og fremmest bly fra akkumulatorerne, bronze fra torpedorørene og legeret stål fra trykskrogene. Her var det ikke-minerede Hørup Hav velegnet med vanddybder ved vragene fra 14 til 30 meter, rolige vandforhold og nærhed af losningshavn i Sønderborg.

Var resultatet af Søværnets efterforskning ret beskedent, viste bjergningsselskabernes initiativer sig anderledes effektive med hensyn til opsporing af de sænkede vrag. Fyrdirektoratets og Marineministeriets bjergningstilladelse blev i juni 1948 overdraget til entreprenør Henry Andersen, Kastrup, således som det fremgår af kontrakten, der omtaler hæveretten til fem ubådsvrag, der ligger sunket i Hørup Hav på nøje angivne positioner: To ud for Grønmark på positionen $54^{\circ} 53,2 \mathrm{~N} /$ $9^{\circ} 52,5 \mathrm{E}$, to mellem det gamle Høruphav og Kegnæs på $54^{\circ} 54,1 \mathrm{~N} /$ $9^{\circ} 54,7 \mathrm{E}$ og ét i Lillehavet. ${ }^{15}$ Fra to stenfiskerfartøjer, "Elisa " og "Kirsten Jensen “ (skipper Otto Olsen) blev der bjerget fra ubådsvragene $\mathrm{i}$ 


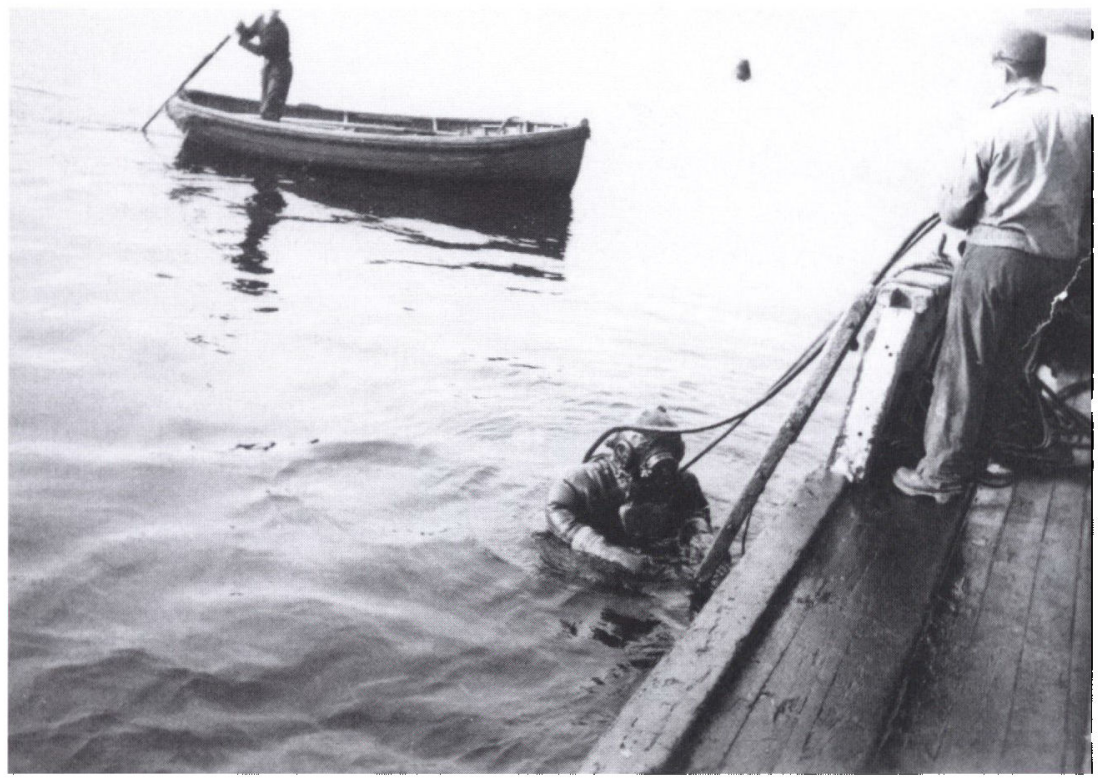

Dykning efter vraggods fra stenfiskerfartøjet "Elisa" $i$ Horup Hav 1949. Der blev bjerget fra ubådsvragene i Hørup Hav og i Flensborg Fjord $i$ årene 1948 til 1951. Privat foto.

Hørup Hav og i Flensborg fjord i årene 1948 til 1951. Vragene var bl.a. lokaliseret ved hjælp af Viggo Høys fars angivelser, og deres positioner blev fastlagt af dykkere i årene 1949 til 1951. Af bjergningsselskabet "Switzer «s arkiver fremgår, at der med sikkerhed påvistes vrag på følgende positioner: $54^{\circ} 53,4 \mathrm{~N} / 9^{\circ} 52,5 \mathrm{E}-54^{\circ} 53,4 \mathrm{~N} / 9^{\circ} 52,7 \mathrm{E}-54^{\circ} 53,4 \mathrm{~N} /$ $9^{\circ} 52,8 \mathrm{E}-54^{\circ} 53,2 \mathrm{~N} / 9^{\circ} 52,5 \mathrm{E}$, altså fire meget tætliggende vrag i den vestlige del af Hørup Hav og alle i god overensstemmelse med Peter Høys anvisninger og samstemmende med de positionsangivelser, der forelå fra 1948. ${ }^{16}$ Vragene lå i 20-26 meters dybde og bar præg af tidligere foretagne sprængning. Ét af vragene havde en anslået længde på 75 meter.

I kontrakterne mellem bjergningsentreprenøren og Fyrdirektoratet/Marineministeriet gives der Søværnet forkøbsret til ophentet materiel af militær interesse fra de sænkede ubåde i Hørup Hav, herunder ammunition, sprængstof, våben og regnemaskiner, og Søværnet betinger sig ret til i studieøjemed at besigtige bådene eller dele deraf samt militært udstyr, der bringes til overfladen. Indberetning herom skal ske til marinedistriktet i Sønderborg, hvortil også alle bjergede 


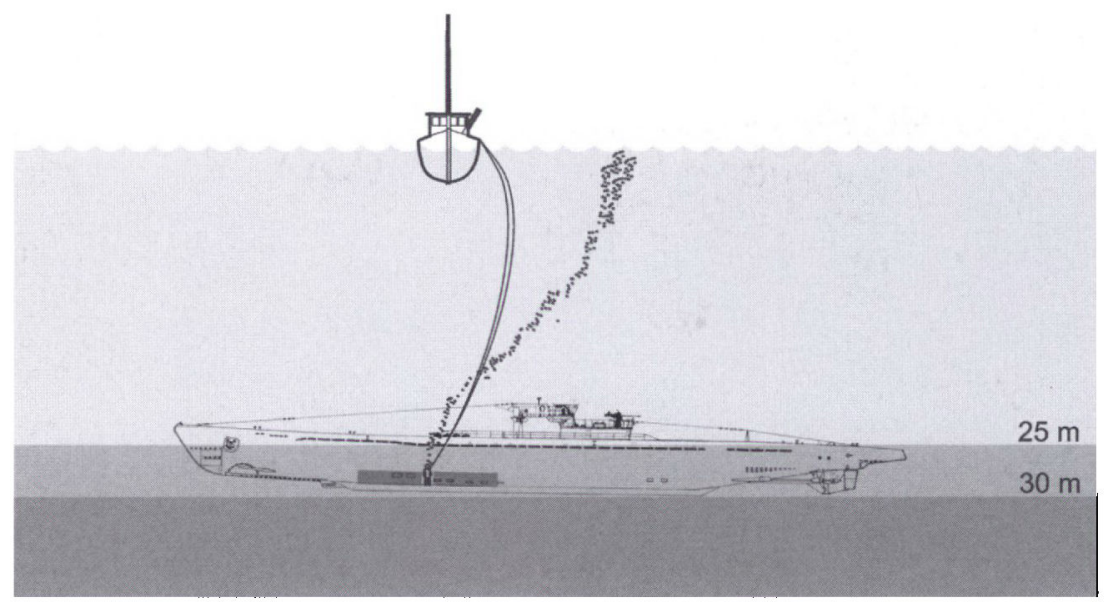

Det var en vanskelig og farlig opgave at dykke efter vraggods. På skitsen ses placeringen af akkumulatorerne $i$ ubåd type IX C. For at nå frem til akkumulatorerne $i$ bunden af vragene, måtte dxkket og overste del af skroget med mandskabsrummene forst klippes fri eller sprænges bort. Foto: Dykkehistorisk Tidsskrift 2004.

bøger, kort, planer og lignende skal afleveres. Såfremt der findes sprængstof i skroget, skal marinedistriktet underrettes.

Der foreligger interessante autentiske beskrivelser af dykkeaktiviteterne ved disse ubåde, idet dykkeren Harry Olsen, der dengang knap 30 år gammel arbejdede på de nævnte bjergningsskibe, levende fortæller om sine oplevelser som erhvervsdykker i Hørup Hav. Ydermere førte han en minutiøs dagbog over sine dykninger $i$ farvandet $i$ perioden 15. november 1950 til 13. marts 1951. Med hans tilladelse gengives her uddrag af denne spændende beretning, som i øvrigt er offentliggjort i sin helhed. ${ }^{17}$ Han og en kollega, Peter Christensen, var talrige gange ud for Grønmark nede ved vragene af to ubåde af type VII C (totalvægt 1.070 tons) og én af type IX C (totalvægt 1.540 tons), store oceangående ubåde med en besætning på 44-48 mand, samt én af typen XXIII. Kun en mindre del af bådene stak op over det 45 meter tykke lag af dynd, nogle lå med slagside. Bådene var alle beskadigede efter tidligere foretagne sprængninger af englænderne.

Af samtale med Harry Olsen og af hans dagbog fremgår det tydeligt, at dykningerne og bjergningen af materiale fra ubådene var vanskelige og risikofyldte, således som det skete i det kolde og mørke vand, hvor dykkeren ofte måtte føle sig frem inde i selve ubåden på grund af dyndet, der ikke tillod lyset at trænge igennem. Dykkerne 


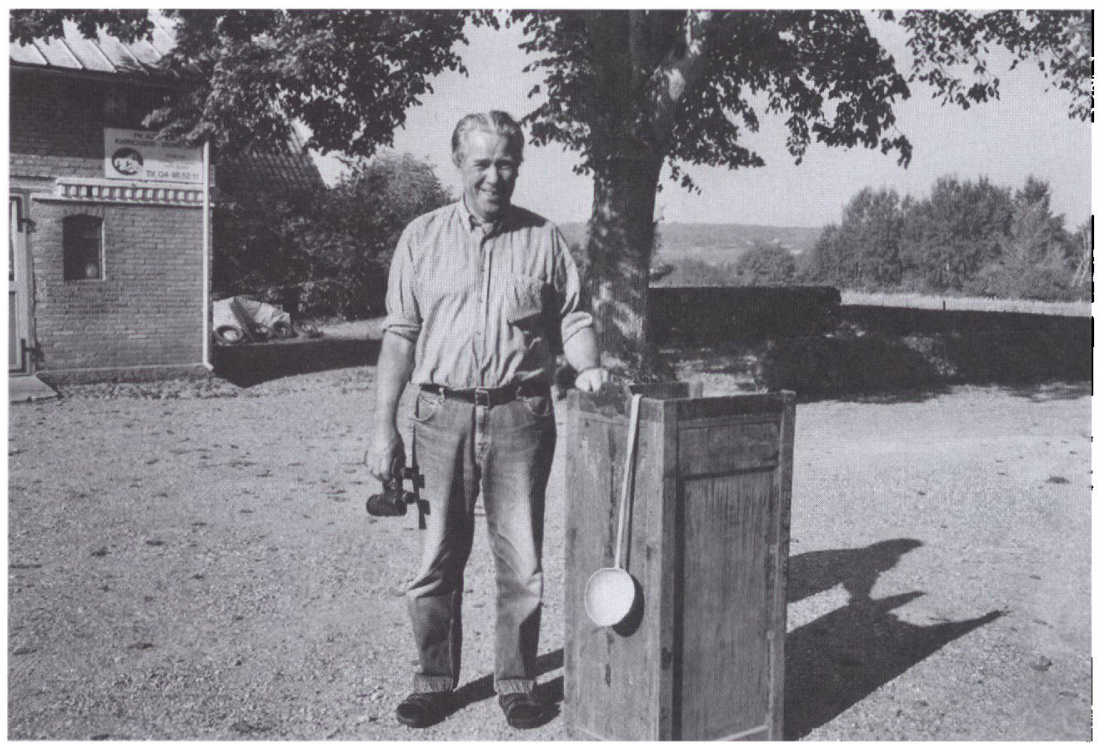

Viggo Høy på gårdspladsen $i$ Grønmark på Kegnæs. Han står ved en bakelitkasse fra en akkumulator, samt med en kikkert og en stor suppeske, alt ophentet fra en sanket ubåd i farzandet, der anes bag ham. Foto: Anton Marckmann.

havde derfor $\mathrm{i}$ forvejen sat sig grundigt ind $\mathrm{i}$ bådenes konstruktion og indretning ved at studere skitser over disse. For at nå frem til akkumulatorerne $\mathrm{i}$ bunden af vragene, måtte dækket og øverste del af skroget med mandskabsrummene først klippes fri eller sprænges bort; i sidste tilfælde måtte man vente til næste dag med at dykke igen. For hver ny situation, der således ændrede på vraget, blev det indtegnet på skitsen, så begge dykkere, når de afløste hinanden, løbende var orienteret om de aktuelle forhold inde i skroget.

Akkumulatorerne, hvoraf der var talrige (60-100) i hver båd, var placeret $\mathrm{i}$ beholdere af bakelit eller tyk papmaché og omsluttet af en gummisæk, der skulle modvirke beskadigelser, når fartøjet bevægede sig uroligt i søen. Efter frigørelse af den $2-400 \mathrm{~kg}$ tunge akkumulator blev den omviklet med tov og hejst op af dykkerskibets kran, åbnet og tømt for syren, der gik udenbords, således som V.H., der flere gange fik lov til at følge arbejdet ombord på »Kirsten Jensen «, kan berette om. I hver af de store ubåde var der mellem 40 og 60 tons bly, og Harry Olsen nåede $\mathrm{i}$ de fire måneder i 1950/51 at medvirke ved opfiskningen af ca. 200 akkumulatorer. 
Dykkeren beskriver besværlighederne ved at arbejde i dybet, hvor nedstyrtende metalelementer undertiden blokerede for dykkerens udstigning fra skroget, hvor skarpt og fremspringende stål rev hul i dykkerdragten, og hvor luftslangen kunne blive afklemt under arbejdet. Hertil kommer en yderligere risiko i form af vragenes mulige indhold af ammunition og andre eksplosive emner, fx torpedoer. Også dykkersygen voldte kvaler med stærke smerter $\mathbf{i}$ arme og ben, trods nøje overholdelse af angivelserne for dykketid og dekompression i de da gældende tabeller i Søværnets lærebog i dykning. Disse tabeller er siden blevet reviderede. Dykkerne tog det imidlertid ikke altid særlig højtideligt med hvor lang tid, de arbejdede $\mathrm{i}$ vragene, således kan man læse, at der blev dykket i op til fem timer i ét træk, »hvilket er for meget «, som der står i dagbogen. Harry Olsen mener, at dykkerne ændrede karakter i dybet, så de mistede den normale tidsfornemmelse. Selv efter en tur i tanken holdt der sig efter så lang tids dykning stærke smerter, hvorfor dykkerne tyede til alkohol som dulmende middel, men der måtte nogle gange hele 14 snapse til, før generne var til at holde ud.

Efter dagens dykkerarbejde blev det bjergede materiale sorteret under tilbageturen til havnen i Sønderborg. Det, der var værdiløst skrot blev kastet udenbords i Sønderborg bugt, så her må ligge en hel del.

Hen mod afslutningen af dykningsarbejdet på IXC båden og de to VII-C både blev mandskabet kontaktet af fritidsfisker og savskærer, Hans Valentin, Høruphav, som fortalte, at han ved fiskeri sammen med sin søn Ejnar længere inde i havbugten havde fået hold på, hvad han mente kunne være en ubåd. Det viste sig at være tilfældet. Der var tale om en mindre ubåd af typen XXIII, der fandtes liggende på positionen $54^{\circ} 53,8 \mathrm{~N} / 9^{\circ} 54,8 \mathrm{E}$ på 14 meters vanddybde. Det vil sige $\mathrm{i}$ Lillehavet, og faktisk i god overensstemmelse med Pæ Malers beskrivelse af stedet for den vestligste af de to, han så gå ned den 5. maj 1945. Vraget blev, efter indhentet bjergningstilladelse i juli 1951, slæbt ind på lavere vand, hvor det blev tømt for metal og bly. Som tak for sin medvirken fik savskæreren udbetalt en dusør på $2.000 \mathrm{kr}$.

Man kan håbe, at aflønningen stod mål med dykkernes anstrengelser. Og det gjorde den: Udover den faste hyre fik dykkerne en procentdel af værdien af det afsatte skrot. I starten af dykningerne blev det værdifulde bly og metallerne solgt til Sverige. Senere blev det påbudt at afsætte stålet til Stålvalseværket i Frederiksværk eller danske skrothandlere. 


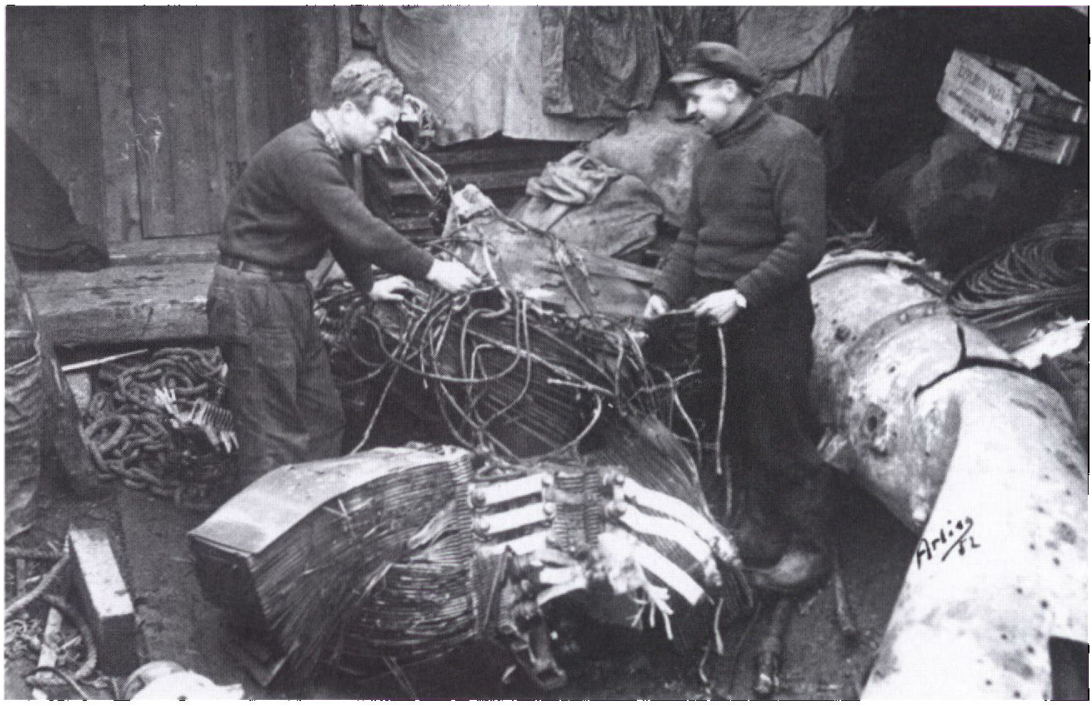

Akkumulatorer og torpedorer bjerget fra en ubåd. Dykker Harry Olsen til venstre, skipper Otto Olsen til højre. Efter dagens dykkerarbejde blev det bjergede materiale sorteret under tilbageturen til havnen i Sønderborg. Privat foto.

Ved at høre og læse om disse hændelser bliver man imponeret over dykkernes arbejdsindsats. Det må have krævet en stærk fysik, en god kondition, megen koldblodighed og en robust psyke for at klare strabadserne. At Harry Olsen kunne honorere disse krav ses af, at han i dag i en alder af 84 år lever i bedste velgående, stadig med interessen for dykning i behold, dog ikke længere som aktiv udøvende.

Det er værd at notere, at Direktoratet i november 1951 gav samme rederi tilladelse til bjergning af endnu et ubådsvrag, der lå lidt længere mod øst i Lillehavet, nemlig på positionen $54^{\circ} 53,3 \mathrm{~N} / 9^{\circ} 55,7 \mathrm{E}$. Dette vrag er utvivlsomt den ubåd, som Pæ Maler så gå ned mellem Vibæk og Kongshoved. Bjergningsentreprenøren anfører i sin ansøgning, at ubåden »er en lille type, ca. 30 meter lang, ligger på ret køl i 13-14 meters dybde nedsunket $\mathrm{i}$ mudder til tårnet, og med stævnen ragende to meter over mudderet. Midtskibs er der foretaget sprængninger«. Hvorvidt bjergningstilladelsen blev udnyttet, foreligger der ingen vidnesbyrd om.

Om de ved Kegnæs Rev sænkede to ubåde fortæller Ejnar Valentin, at den ene ca. 1951 af et tysk bjergningsselskab blev slæbt ind på lavere vand ved Klinten og her tømt for sit indhold. Endelig i 1953 
udfoldede endnu et tysk bjergningsfartøj bestræbelser på at få yderligere skrot op fra de sunkne fartøjer ud for Grønmark. Christen Wolf, Høruphav, der senere blev fører af den lille færge mellem Høruphav og Kegnæs, beretter om en tragisk hændelse, der overgik én af de tyske sømænd, som, uset af de andre, faldt overbord fra færgen og druknede. Først flere måneder senere drev hans lig i land ved Lambjerglund.

Herefter sænkede der sig dyb tavshed over ubådsvragene i Hørup Hav. Bjergningen var ikke længere lønsom, og der skulle gå mange år, før der igen hørtes nyt.

\section{Nutidig interesse for ubådsvragene}

Sportsdykkere har jævnlig dykket på de anførte positioner i Hørup Hav, men uden at støde på vraggods, der kunne identificeres som stammende fra de sænkede ubåde. I 2001 dykkede to amatørdykkere fra Sønderborg sportsdykkerklub ud for Grønmark og stødte her på et vrag, som formodedes at være resterne af en ubåd, der i bredde og længde svarede til en type XXIII med det karakteristiske smalle for$\mathrm{dæk}$, men sigtbarheden var ringe (under $10 \mathrm{~cm}$ ), og skroget forsvandt ind $i$ en sandbanke. ${ }^{18}$ Senere dykninger har imidlertid vist, at disse vragrester snarere er en 15-20 meter lang pontonstrygemagnet (induktionsspole), som blev anvendt af minestrygere til aktivering (detonering) af nedkastede magnetminer. ${ }^{19}$

I juli 2002 var sportsdykkerne særlig aktive i farvandet. Der blev herunder taget adskillige fotografier af store, sprængte metalstykker, der lå spredte på bunden ud for Grønmark, men om de stammer fra en ubåd er tvivlsomt. Også medierne viste stor interesse i dykningerne med omtale herom i avisartikler og reportage i TV. Man luftede tanker om at gøre Hørup Hav til en turistattraktion, hvor dykkerne skulle tv-transmittere fra vragene til publikum på ledsagebåden men det er hidtil blevet ved tanken. Til gengæld er havområdet, trods bundens tykke dynd- og mudderlag, blevet en attraktiv tumleplads for sportsdykkere. 

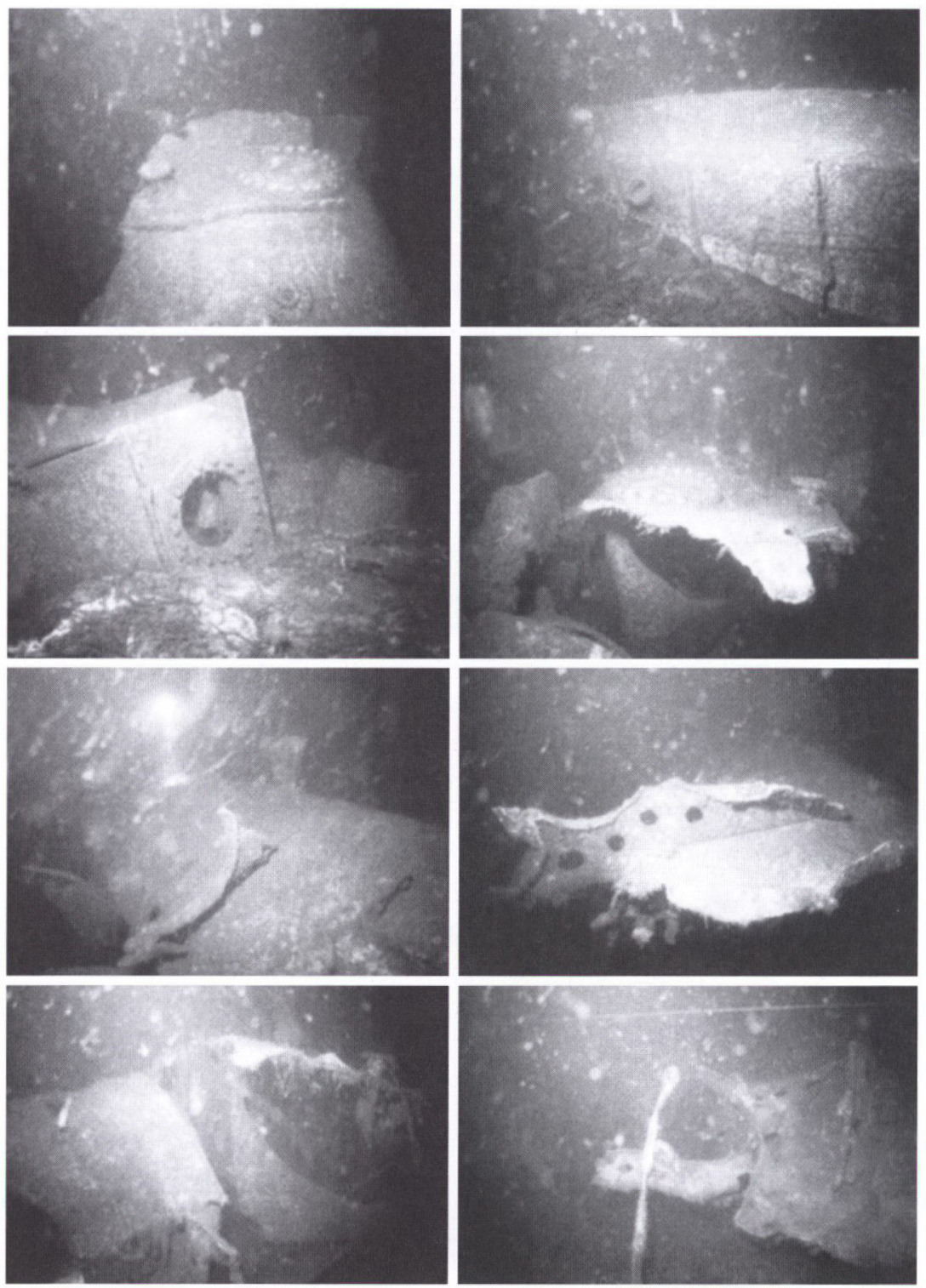

Vragrester på bunden af Horup Hav ud for Gronmark på positionen $54^{\circ} 53,21 \mathrm{~N} /$ $9^{\circ} 52,11 E$. I 2001 dykkede to amatordykkere fra Sønderborg sportsdykkerklub ud for Gronmark og stødte her på et vrag, som formodedes at vare resterne af en ubåd. Senere dykninger har imidlertid vist, at vragresterne snarere er en induktionsspole, som blev anvendt af minestrygere til detonering af nedkastede magnetminer. Fotos: Soren Hertz-Christensen, Høruphav. 


\section{Sammenfatning og perspektiv}

Det er ved denne beretning lykkedes at sammenfatte væsentlige fakta om de turbulente begivenheder i Hørup Hav i maj 1945 og om de efterfølgende bestræbelser på at lokalisere og bjerge de sænkede ubåde, takket være øjenvidner, der i dag er højt oppe i årene. Ved hjælp af deres gode hukommelse og fortælleevne, suppleret med søgen på Internettet og i tilgængeligt arkivmateriale og litteratur om emnet, er ubådenes skæbne fulgt frem til i dag, og der er hermed ydet et bidrag til farvandets historie. Selvom alt ikke er afdækket, er det dog forbløffende, så rimelig god overensstemmelse der er mellem de fleste (af hinanden uafhængige) kilders oplysninger om de her omtalte hændelser i Hørup Hav.

Det kan fastslås, at der er sikre beviser på, at der blev selvsænket seks tyske ubåde i farvandet mellem Als og Kegnæs den 5. maj 1945 om morgenen. Dog kan det reelle antal meget vel være otte, måske ni. Senere i 1945 blev vragene nedsprængt af engelske styrker, og i 1946 foranstaltede Søværnet en eftersøgning. I årene 1948 til 1953 blev de sænkede ubåde lokaliseret af bjergningsselskaber og tømt for deres indhold af værdifulde metaller.

Der siges, at havet sletter alle spor. Dette er kun en sandhed med modifikationer. Det gælder i hvert fald ikke for de her omtalte vrag. Sporene må stadig være der, om end de forekommer som sprængte metalstykker, der forsvinder dybere og dybere $\mathrm{i}$ mudder, som tiden går.

Tilbage står det uløste spørgsmål: Ligger der endnu på bunden af Lillehavet en (type XXIII?) ubåd, som ikke er tømt af vragfiskere og som ikke er identificeret af danske sportsdykkere? Udfordringen gives hermed videre til de aktive amatørdykkere, som ved hjælp af moderne teknik måske kan løfte sløret for, hvad der skjuler sig i dyndet.

\section{NOTER}

1. Krag, E.: En $ø$ bliver til. I: Huhle, R.: Bogen om Als. Åbenrå 1956, s. 9-31.

2. Tækker, H.: Træk fra Klintens hi- storie. Lokalhist. Foren. f. Hørup sogn, årsskrift 1968, s. 1-11.

3. Kristensen, H. Skov: Tyske militære anlæg på Als og Sundeved. I: 
Kristensen, H. Skov og Adriansen, I.: Als og Sundeved 1940-45. Hist. Samf. f. Als og Sundeved 1995, s. 189-190.

4. Miller, D.: Ubåde. Historien om Tysklands frygtede undervandsvåben. I dansk oversættelse. Billesø og Baltzer 2002, s. 168-169.

5. Kristensen, H. Skov: Tyske militære anlæg på Als og Sundeved. I: Kristensen, H. Skov og Adriansen, I.: Als og Sundeved 1940-45. Hist. Samf. f. Als og Sundeved 1995, s. 179.

6. Christensen, P. A.: En beretning om Horup Klint. Lokalhist. Foren. f. Hørup sogn, årsskrift 1968, s. 1728.

7. ibid.

8. http:/www.vrakdykning.com/ rabat

9. Miller, D.: Ubåde. Historien om Tysklands frygtede undervandsvåben. Billesø og Baltzer 2002, s. 169. Das Schicksal der deutschen U-Boote. Heidenheimer Zeitung, Heidenheim 1950. Gröner, E.: Die deutschen Kriegsschiffe 18141945. Bd. 3. Gernard \& Graefe verlag, Koblenz, 1985, s. 66-136. http://uboat.net/boats. Rössler,
E.: U-bootyp XXIII. Bernard \& Graefe, Bonn. 2002.

10. Das Schicksal der deutschen U-Boote. Heidenheimer Zeitung, Heidenheim. 1950.

11. Rössler, E.: Geschichte des deutschen U-Bootsbaus, bd. 1 \& 2 , Bonn. 1996.

12. Rössler, E.: Die deutschen U-Boote und ihre Werften. Koblenz. 1990.

13. Rössler, E.: U-Boot Typ XXIII. Bernard \& Graefe, Bonn. 2002.

14. Rigsarkivet, FOARK, Marinestaben, arkivnr. 301.007: journalsag 512/1946.

15. Fyrdirektoratets journaler nr. 566/ 1948, nr. 592/1951 og nr. 622/1951.

16. Fra "Switzer«s arkiver: i "Snorklen«, medl. blad f. Sønderborg dykkerklub, 2001.

17. Olsen, H.: Vragdykker Olsens dagbog. Dykkehist. Tidsskr. 2004 (22), s. 8-22.

18. Snorklen. Medl. blad for Sønderborg dykkerklub, 2001.

19. Meyer, K.: Hochsee-Minensuchboote 1939-1945. Mittler \& Sohn, Hamburg, Berlin, Bonn, 2004, s. 664.

Foruden de i artiklen næunte personer takkes Sven E. Jørgensen, Sabro, samt Poul Erik Pedersen og Flemming Hansen, begge Fredericia, for at have stillet oplysninger og materiale til rådighed for dette arbejde. 